\title{
Miller Fisher syndrome
}

\author{
Suresh Kumar Gupta, ${ }^{1}$ Kunal Kishor Jha ${ }^{2}$ Mhd Diaa Chalati, ${ }^{3}$ Losan Tareq Alashi ${ }^{4}$
}

${ }^{1}$ Department of Internal Medicine/Geriatrics, Forest Glen Medical Center, Silver Spring,

Tennessee, USA

${ }^{2}$ Critical Care Medicine, Geisinger Medical Center, Danville, Pennsylvania, USA

${ }^{3}$ Department of Internal Medicine, University of Sharjah College of Medicine, Sharjah, United Arab Emirates

${ }^{4}$ University of Jordan, Amman, Jordan

\section{Correspondence to}

Dr Kunal Kishor Jha, Research

Fellow, Critical Care Medicine

Geisinger Medical Center,

Danville, PA; friendsforever.

kunal@gmail.com

Accepted 29 September 2016

\section{SUMMARY}

A man aged 30 years presented to the emergency department (ED) with ataxia, areflexia, facial weakness, ophthalmoplegia, extremity weakness and back pain for 4 days. 4 days prior to attending the ED, the patient had suffered from diarrhoea for 2 weeks. The diagnosis of Miller Fisher syndrome was performed on the dual basis of clinical features in addition to an investigations report. Nerve conduction studies and anti-GQ1b IgG antibody analysis were requested. Once IgA deficiency was ruled out, the patient was started on intravenous immunoglobulin (400 mg/kg/day).

\section{BACKGROUND}

Guillain-Barre syndrome (GBS) is an acute, immune-mediated, monophasic illness usually triggered by a preceding infection. Miller Fisher syndrome (MFS), a clinical variant of GBS, occurs in $\sim 5 \%$ of cases in the USA, 25\% of cases in Japan and is characterised by areflexia, ophthalmoplegia and ataxia. ${ }^{1}$ Extremity weakness, a major symptom of GBS, will develop in approximately one-quarter of MFS patients, further affirming the link between these two disorders. Incomplete forms of MFS exist, including acute ataxic neuropathy without ophthalmoplegia and acute ophthalmoplegia without ataxia. $^{2}{ }^{3}$ Anti-GQ1b is an antiglanglioside antibody that is self-reactive to the GQ1b ganglioside component of a nerve and is present in about $85-90 \%$ of all patients with MFS. ${ }^{4} 5$ In addition, the GQ1b antibody is strongly associated with oculomotor nerves lesion and hence can also be found in patients with prominent oculomotor weakness and GBS.

The initial diagnosis of GBS is based on the clinical presentation. Lumbar puncture and cerebral spinal fluid (CSF) analysis of patients with GBS often reveals albuminocytologic dissociation. This describes an increase in CSF protein while cell count remains normal, that is, $<5$ cells $/ \mathrm{mm}^{3}$, and is initially present in about $50-66 \%$ of GBS patients following their first week of symptoms, and in $\geq 75 \%$ of patients in their third week. ${ }^{267}$ Here, we present a case of MFS made evident by the presence of lower back pain, extremity weakness in addition to the characteristic triad of ataxia, ophthalmoplegia and areflexia.

\section{CASE PRESENTATION}

A man aged 30 years presented to the emergency department (ED) after suffering 4 days of multiple symptoms, including double vision, slurred speech and difficulty with his coordination, walking and hand movements, as well as finger numbness. The patient's symptoms began 2 days after he returned from a trip to Montreal, about 2 weeks prior to his admittance to the ED. The patient's symptoms began with fatigue and developed into a fever of $103^{\circ} \mathrm{F}$ (at its peak), accompanied by severe diarrhoea that lasted for over a week. The diarrhoea had stopped 6 days previously; however, he then developed neurological symptoms such as double vision, light headedness, stumbling while walking, numb finger tips and odd chewing sensations. In addition, the patient also reported of lower back pain, was easily fatigued, had clumsier handwriting/ typing, dropping of right eye as well as a slightly asymmetrical face due to weakness of right side of face. The patient denied worsening of double vision with any particular eye movement, trouble breathing and weakness of hand bilaterally. No neck pain, urinary retention, ileus or arrhythmia was noted. On review of history, there was no significant past, family, medical, surgical or allergy history.

The patient was examined and the following measurements recorded; temperature $98.3^{\circ} \mathrm{F}$, heart rate: $78 \mathrm{bpm}$, respiration rate: $17 \mathrm{bpm}$, blood pressure: $128 / 68 \mathrm{~mm} \mathrm{Hg}$ and partial pressure of oxygen $\left(\mathrm{pO}_{2}\right)$ : 99\%. A head, eyes, ears, nose and throat examination was nomocephalic/atraumatic and the cardiac, pulmonary and gastrointestinal examination were also found to be normal.

With regard to the mental status of the patient, he was alert and fully oriented. He had no aphasia or dysarthria and comprehension of language was normal. The patient's pupils were equal, round and reactive to light and accommodation; however, there was weakness with medial gaze and up gaze on the right eye. Extraocular movement on the left eye was intact. Weakness on the right side on the face was present. V1-V3 was intact to light touch (LT). Furthermore, hearing was intact and tongue was midline. Strength was $5 / 5$ throughout, except the left triceps. LT and pinprick (PP) sensation were intact in the bilateral $(\mathrm{B} / \mathrm{L})$ upper extremity and stocking gradient was present to $\mathrm{PP}$ in the $\mathrm{LE} \mathrm{B} / \mathrm{L}$. Reflexes were $0+$ throughout while co-ordination testing revealed significant dysmetria/ataxia for finger to nose as well as heel to shin bilaterally. Gait examination was deferred.

\section{INVESTIGATIONS}

Investigations such as complete blood count, complete metabolic panel, blood culture, CSF examination and culture, CT scan without contrast to rule out stroke and MRI of the brain and cervical spine with and without contrast were ordered. The patient's NIH stroke scale score was $3 / 42$ and his brain CT scan and MRI were normal. Serum thiamine and cyanocobalmin level were normal and his 
Table 1 Investigation report

\begin{tabular}{|c|c|c|c|c|c|}
\hline Investigations & 21 June 2016 & 22 June 2016 & Investigations & 21 June 2016 & 22 June 2016 \\
\hline $\mathrm{Na}+(136-145 \mathrm{meq} / \mathrm{L})$ & $137 \mathrm{meq} / \mathrm{L}$ & $138 \mathrm{meq} / \mathrm{L}$ & RBC (4.7-6.1 million cells/ $\mu \mathrm{L})$ & 4.79 million cells/ $\mu \mathrm{L}$ & 4.5 million cells/ $\mu \mathrm{L}$ \\
\hline $\mathrm{K}+(3.5-5.0 \mathrm{meq} / \mathrm{L})$ & $4.6 \mathrm{meq} / \mathrm{L}$ & $4.7 \mathrm{meq} / \mathrm{L}$ & $\mathrm{Hb}(13-17 \mathrm{~g} / \mathrm{dL})$ & $14.9 \mathrm{~g} / \mathrm{dL}$ & $13.6 \mathrm{~g} / \mathrm{dL}$ \\
\hline $\mathrm{Cl}(98-106 \mathrm{meq} / \mathrm{L})$ & $100 \mathrm{meq} / \mathrm{L}$ & 102 & Hct $(41-51 \%)$ & $43.7 \%$ & $40.2 \%$ \\
\hline $\mathrm{CO}_{2}$ (23-28 meq/L) & $27 \mathrm{meq} / \mathrm{L}$ & $26 \mathrm{meq} / \mathrm{L}$ & WCC $(4.5-11 \mathrm{~K} / \mathrm{mcL})$ & $9.5 \mathrm{~K} / \mathrm{mcL}$ & $5.8 \mathrm{~K} / \mathrm{mcL}$ \\
\hline Glucose (70-100 mg/dL) & $82 \mathrm{mg} / \mathrm{dL}$ & $100 \mathrm{mg} / \mathrm{dL}$ & Platelet $(150-450 \mathrm{~K} / \mathrm{mcL})$ & $417 \mathrm{~K} / \mathrm{mcL}$ & $388 \mathrm{~K} / \mathrm{mcL}$ \\
\hline BUN (8-20 mg/dL) & $15 \mathrm{mg} / \mathrm{dL}$ & $14 \mathrm{mg} / \mathrm{dL}$ & MCV (80-96 fL/red cell) & $91.2 \mathrm{fL} / \mathrm{red}$ cell & $89.3 \mathrm{fL} / \mathrm{red}$ cell \\
\hline $\mathrm{Cr}(0.7-1.3 \mathrm{mg} / \mathrm{dL})$ & 1 & 0.9 & MCH (27-33 pg/cell) & $31.1 \mathrm{pg} /$ cell & $30.2 \mathrm{pg} / \mathrm{cell}$ \\
\hline Total Ca (9-10.5 mg/dL) & $9.5 \mathrm{mg} / \mathrm{dL}$ & $9.2 \mathrm{mg} / \mathrm{dL}$ & CSF values & & \\
\hline $\mathrm{Mg}(1.5-2.4 \mathrm{mg} / \mathrm{dL})$ & $2.4 \mathrm{mg} / \mathrm{dL}$ & $2.4 \mathrm{mg} / \mathrm{dL}$ & Colour & Colourless & \\
\hline Bilirubin total $(0.3-1.2 \mathrm{mg} / \mathrm{dL})$ & $0.8 \mathrm{mg} / \mathrm{dL}$ & & Appearance & Clear & \\
\hline AKP (36-92 U/L) & $65 \mathrm{U} / \mathrm{L}$ & & CSF WBC (0-5 cells/ $/ \mu \mathrm{L})$ & 2 cells $/ \mu L$ & \\
\hline ALT (0-35 U/L) & $70 \mathrm{U} / \mathrm{L}$ & & CSF lymphocytes & $80 \%$ & \\
\hline AST $(0-35 \mathrm{U} / \mathrm{L})$ & $30 \mathrm{U} / \mathrm{L}$ & & CSF neutrophils & $20 \%$ & \\
\hline Albumin & $3.7 \mathrm{~g} / \mathrm{dL}$ & & CSF glucose $(40-80 \mathrm{mg} / \mathrm{dL})$ & $55 \mathrm{mg} / \mathrm{dL}$ & \\
\hline TSH (0.5-5 mlu/L) & $1.62 \mathrm{mlu} / \mathrm{L}$ & & CSF protein (15-60 mg/dL) & $31 \mathrm{mg} / \mathrm{dL}$ & \\
\hline Gq1b antibody & +ve & & Cryptococcus Ag CSF & - ve & \\
\hline ESR (0-15 mm/hour) & $10 \mathrm{~mm} /$ hour & & CSF Borrelia Ab IgG/lgM $(\mathrm{N}<0.9)$ & $<0.90$ & \\
\hline IgA gammaglobulin (70-300 mg/dL) & $247 \mathrm{mg} / \mathrm{dL}$ & $300 \mathrm{mg} / \mathrm{dL}$ & CSF culture & - ve & \\
\hline AFB culture and direct smear & -ve & & CSF West Nile virus and other virus detection & - ve & \\
\hline
\end{tabular}

oligoclonal IgG band was negative. Serum mycoplasma IgG titre was negative and culture of his stool was negative for enteric pathogens, including Campylobacter jejuni. GQ1b antibody was positive, suggestive of MFS. Electromyography was not performed. Nerve conduction study and cranial MRI including T1, $\mathrm{T} 2$ and diffusion-weighted images demonstrated no abnormality. The investigation report is attached here (table 1).

\section{TREATMENT}

Based on the history and the investigational findings, it was believed that he was suffering from a rare variant of GBS, that is, MFS. Before initiating intravenous immunoglobulin (IVIG) treatment, we measured the patient's IgA level and tested for the presence of albuminocytologic dissociation in his CSF. Both the investigations were normal and we proceeded to treat with acetaminophen $650 \mathrm{mg}$ Q4 PRN and IVIG $25000 \mathrm{mg}(0.4 \mathrm{~g} / \mathrm{kg} /$ day) for 5 days. The patient's negative inspiratory force (NIF) and vital capacity (VC) were checked every 4 hours. Fortunately, his NIF did not drop below 20, and so intubation was not required. The patient's symptoms improved with IVIG treatment. Even so, we referred him to a better equipped facility on third day of admission for fear that his symptoms may further deteriorate. Currently, he is in good health and his neurological symptoms are improving.

On review of his treatment history, 5 days after initiation of the treatment, his symptoms including ophthalmoplegia, ataxia and weakness of his lower extremities started to improve. After gradual improvement in his symptoms, he was discharged on the 14th day after admission. On his next follow-up on the 45th day in our office, he reported complete resolution of ataxia, dysarthria and ophthalmoplegia. His deep tendon reflexes were normal on examination.

\section{DISCUSSION}

GBS is an autoimmune disorder encompassing a heterogeneous group of acute, immune-mediated polyneuropathies and occurs with an overall incidence of 1-2 per 100000 per annum, worldwide. ${ }^{2}$ Although all age groups can be affected, after the first decade of life, there is an apparent $20 \%$ increase in incidence with every 10-year lived. Progressive, relatively symmetric muscle weakness is the characteristic clinical feature of GBS and is often accompanied by depressed or absent deep tendon reflexes. On average, patients present within a week of their symptoms manifesting and although weakness in the legs is a common initial symptom, $\sim 10 \%$ of patients present with weakness beginning in either the arms or facial muscles. In addition, severe respiratory weakness is reported to occur in $10-30 \%$ of patients. Facial weakness occurs in $>50 \%$ of cases, oculomotor weakness in up to $15 \%$, oropharyngeal weakness in up to $50 \%$, paresthesia in as many as $80 \%$ of cases, back or extremity pain, in particular in the acute phase of illness, in up to $66 \%$ of patients and dysautonomia occurs in around $70 \%$ of GBS patients. ${ }^{9-12}$

MFS, a rare variant of GBS, typically presents as ophthalmoplegia with areflexia and ataxia. ${ }^{1}{ }^{13}$ In contrast to GBS, respiratory symptoms have been to precede neurological symptoms in about $76 \%$ of MFS cases, and GI involvement is reported in only $4 \%$ of MFS patients. ${ }^{14}$ The presence of anti-GQ1b antibodies is believed to be associated with the pathogenesis of MFS. The ganglioside, GQ1b, can be found in abundance in the paranodal region of the extramedullary portion of the oculomotor, abducens and trochlear nerves, and it is these areas that are most affected by the self-reactive anti-GQ1b antibody. ${ }^{14}$ Similar to GBS, MFS can occur postinfection with 'molecular mimicry' believed to be the main pathogenic mechanism underlying this. ${ }^{4}$ Interestingly, the Gram-negative bacterium, C. jejuni, has been reported in as many as $30 \%$ of GBS cases, making it the most frequent pathogen to trigger this disease. ${ }^{15} \mathrm{MFS}$, in addition to C. jejuni, has also been associated with infection due to bacteria such as Haemophilus influenzae, Mycoplasma pneumoniae and Helicobacter pylori, as well as viral infection from Epstein-Barr virus, varicella-zoster virus, cytomegalovirus and $\mathrm{HIV}^{4}{ }^{15-18}$ A large prospective case-controlled serological study, however, revealed that the associated infective agents for the majority of cases remain unknown. ${ }^{19}$

In general, GBS patients have normal CSF cell counts, that is, $<5$ cells $/ \mathrm{mm}^{3}$; however, mildly elevated CSF cell counts have 
been documented in a minority of GBS patients. In the Massachusetts General Hospital (MGH) study, 110 GBS patients had their CSF cell count measured and $87 \%$ had $<5$ cells $/ \mathrm{mm}^{3}$, $9 \%$ had $5-10$ cells $/ \mathrm{mm}^{3}, 2 \%$ of patients had $11-30$ cells $/ \mathrm{mm}^{3}$, while $2 \%$ had a CSF cell count of $>30$ cells $/ \mathrm{mm}^{3}{ }^{6}{ }^{6}$ In clinical practice, tests for anti-GQ1b IgG antibodies are available commercially and are extremely useful for the diagnosis of MFS. It is important to note however that anti-GQ1b antibodies may also be present in ophthalmoparesis-associated GBS, the pharyngeal-cervical-brachial GBS variant and Bickerstaff encephalitis. ${ }^{45}$ Of note, the normal CSF findings in our patient may have been due to obtaining the sample during the early period of the symptoms.

Other diseases that are known to cause ataxia, areflexia and ophthalmoplegia include: GBS, Bickerstaff's brainstem encephalitis, brainstem stroke, botulism, myasthenia gravis and Wernicke's encephalopathy. MFS is associated with rapid-onset ophthalmoplegia compared with gradual onset in chronic diseases such as myasthenia gravis, and myotonic dystrophy. On the other hand, MFS and cerebellar lesions are similar in presentation; however, lack of lateralisation of ataxia in MFS helps to differentiate these diseases. Similarly, medications and toxins are also known to induce acute onset ataxia. For example, phenytoin, fluorouracil and most notably alcohol can mimic such symptoms. Ataxia associated with chronic alcoholism presents with poor fine motor control of hands, impaired vision and slurring of speech.

Although recurrent MFS is rare disease, it may occur in genetically susceptible individuals. ${ }^{20}$ After comparing the characteristics of patients with recurrent and non-recurrent MFS, they found no obvious electrophysiological or clinical differences except the age of the onset of symptoms. Patients with younger age of presentation experienced recurrent symptoms. ${ }^{21}$

Plasmapheresis and intravenous immune globulin are the main treatments recommended for GBS. Common issues such as when to admit the patient to the intensive care unit and when to consider mechanical ventilation can arise even before a specific treatment is initiated. Unfortunately, randomised, double-blind, placebo-controlled trials for MSF treatments

\section{Learning points}

- Progressive, relatively symmetric muscle weakness is the characteristic clinical feature of Guillain-Barre syndrome (GBS) and is often accompanied by depressed or absent deep tendon reflexes. The weakness can vary from mild difficulty with walking to nearly complete paralysis of all extremity, facial, respiratory and bulbar muscles.

- GBS is an autoimmune disorder encompassing a heterogeneous group of acute, immune-mediated polyneuropathies. Miller Fisher syndrome (MFS) is a variant of GBS, characterised by ophthalmoplegia with ataxia and areflexia.

- The initial diagnosis of GBS is based on the clinical presentation. The diagnosis is confirmed by cerebral spinal fluid analysis and clinical neurophysiology studies. Therefore, these studies should be performed in all patients with suspected GBS.

- Testing for serum IgG antibodies to GQ1b is useful for the diagnosis of MFS and helps to facilitate the use of treatment already established for GBS. cannot be carried out due to the self-limiting clinical course of this disorder. A retrospective analysis, however, performed on 92 consecutive MFS cases reported that IVIG therapy lessened ophthalmoplegia and ataxia to some extent but had no significant effect on the overall outcome, likely due to the frequency of natural recoveries. ${ }^{22}$ Based on the observational data available, complete resolution of ataxia by 1 month and resolution of ophthalmoplegia within 3 months would be acceptable outcome measures. In conclusion, MFS presents with a wide range of clinical features, depending on the triggering agent and the specific immune response.

Contributors SKG and KKJ assembled the case history and investigations from hospital records, critically reviewed, analysed the data and wrote the paper. MDC and LTA assessed the patient data, and critically reviewed the paper.

Competing interests None declared.

Patient consent Obtained.

Provenance and peer review Not commissioned; externally peer reviewed.

\section{REFERENCES}

1 Mori M, Kuwabara S, Miyake M, et al. Haemophilus influenzae infection and Guillain-Barré syndrome. Brain 2000;123(Pt 10):2171-8.

2 Jones HR Jr. Guillain-Barré syndrome: perspectives with infants and children. Semin Pediatr Neurol 2000;7:91.

3 Ho TW, Willison HJ, Nachamkin I, et al. Anti-GD1a antibody is associated with axonal but not demyelinating forms of Guillain-Barré syndrome. Ann Neurol 1999;45:168-73

4 Jacobs BC, Endtz $H$, van der Meché FG, et al. Serum anti-GQ1b lgG antibodies recognize surface epitopes on Campylobacter jejuni from patients with Miller Fisher syndrome. Ann Neurol 1995;37:260-4.

5 Chiba A, Kusunoki S, Obata $\mathrm{H}$, et al. Ganglioside composition of the human cranial nerves, with special reference to pathophysiology of Miller Fisher syndrome. Brain Res 1997:745:32.

6 Verity C, Stellitano L, Winstone AM, et al. Guillain-Barré syndrome and H1N1 influenza vaccine in UK children. Lancet 2011;378:1545.

7 Asbury AK, Cornblath DR. Assessment of current diagnostic criteria for Guillain-Barré syndrome. Ann Neurol 1990;27(Suppl):S21-4.

8 Beghi E, Kurland LT, Mulder DW, et al. Guillain-Barré syndrome. Clinicoepidemiologic features and effect of influenza vaccine. Arch Neurol 1985;42:1053-7.

9 Olivé JM, Castillo C, Castro RG, et al. Epidemiologic study of Guillain-Barré syndrome in children $<15$ years of age in Latin America. J Infect Dis 1997;175 (Suppl 1):S160-4.

10 Carroll JE, Jedziniak M, Guggenheim MA. Guillain-Barré syndrome. Another cause of the 'floppy infant'. Am J Dis Child 1977;131:699-700.

11 Buchwald B, de Baets M, Luijckx GJ, et al. Neonatal Guillain-Barré syndrome: blocking antibodies transmitted from mother to child. Neurology 1999;53:1246.

12 Patja A, Paunio $M$, Kinnunen $E$, et al. Risk of Guillain-Barré syndrome after measles-mumps-rubella vaccination. J Pediatr 2001;138:250

13 Jacobs BC, Hazenberg MP, van Doorn PA, et al. Cross-reactive antibodies against gangliosides and Campylobacter jejuni lipopolysaccharides in patients with Guillain-Barré or Miller Fisher syndrome. J Infect Dis 1997;175:729.

14 Yuki N. Molecular mimicry between gangliosides and lipopolysaccharides of Campylobacter jejuni isolated from patients with Guillain-Barré syndrome and Miller Fisher syndrome. J Infect Dis 1997;176(Suppl 2):S150-3.

15 Kuroki S, Saida T, Nukina M, et al. Campylobacter jejuni strains from patients with Guillain-Barré syndrome belong mostly to Penner serogroup 19 and contain beta-N-acetylglucosamine residues. Ann Neurol 1993;33:243-7.

16 Merkx H, De Keyser J, Ebinger G. Miller Fisher syndrome associated with Mycoplasma pneumoniae infection: report of a case. Clin Neurol Neurosurg 1994;96:96-9.

17 Neisser A, Bernheimer $H$, Berger $T$, et al. Serum antibodies against gangliosides and Campylobacter jejuni lipopolysaccharides in Miller Fisher syndrome. Infect Immun 1997:65:4038-42.

18 Koga M, Yuki N, Tai T, et al. Miller Fisher syndrome and Hemophilus influenzae infection. Neurology 2001;57:686-91.

19 Koga M, Gilbert M, Li J, et al. Antecedent infections in Fisher syndrome: a common pathogenesis of molecular mimicry. Neurology 2005;64:1605-11.

20 Chida K, Nomura H, Konno H, et al. Recurrent Miller Fisher syndrome: clinical and laboratory features and HLA antigens. J Neuro/ Sci 1999;165:139-43.

21 Ishii J, Yuki N, Kawamoto M, et al. Recurrent Guillain-Barré syndrome, Miller Fisher syndrome and Bickerstaff brainstem encephalitis. J Neurol Sci 2016:364:59-64.

22 Yuki N. Fisher syndrome and Bickerstaff brainstem encephalitis (Fisher-Bickerstaff syndrome). J Neuroimmunol 2009;215:1-9. 
Copyright 2016 BMJ Publishing Group. All rights reserved. For permission to reuse any of this content visit http://group.bmj.com/group/rights-licensing/permissions.

BMJ Case Report Fellows may re-use this article for personal use and teaching without any further permission.

Become a Fellow of BMJ Case Reports today and you can:

- Submit as many cases as you like

- Enjoy fast sympathetic peer review and rapid publication of accepted articles

- Access all the published articles

- Re-use any of the published material for personal use and teaching without further permission

For information on Institutional Fellowships contact consortiasales@bmjgroup.com

Visit casereports.bmj.com for more articles like this and to become a Fellow 